\author{
비거세 한우 집단에 있어 성장형질과 도체형질에 대한 \\ 유전모수의 추정 \\ 박철진*박영일** \\ 농협중앙회 가축개량사업소*, 서울대학교**
}

\title{
Estimation of Genetic Parameters for Growth and Carcass Traits in Hanwoo Bull Populations
}

\author{
Park. C. J.* and Y. I. Park** \\ Livestock Improvement Main Center, N.A.C.F.*, Seoul National University**
}

\begin{abstract}
Genetic parameters for growth and carcass traits were estimated on the basis of the data from 3,415 heads of Hanwoo bulls tested at Livestock Improvement Main Center. The data were divided into two groups : the first period group consisted of 1,592 heads of bulls tested in individual pens from 1986 to 1990 and the second period group consisted of 1,823 heads of bulls tested in group pens from 1991 to 1996. The testing period was from 6 to 18 months of age in the first period group and 10 to 22 months of age in the second period group. The average daily gains during 6 to 12 months and 12 to 18 months were $1.01 \mathrm{~kg}$ and $0.77 \mathrm{~kg}$, respectively, in the first period group and $0.80 \mathrm{~kg}$ and $0.95 \mathrm{~kg}$ in the second period group, and the compensated growth appeared to have occurred in the second period group.

The heritability of body weight at 12 months estimated was 0.37 during the first period and 0.47 during the second period. The heritability of body weight at 18 months was 0.29 during the first period and 0.33 during the second period. The heritability of average daily gain during $6 \sim 12$ months estimated was 0.26 for the first period and 0.33 for the second period. The heritability of average daily gain during 12 18 months estimated was 0.11 for the first period and 0.22 for the second period. The heritabilities of body weights and average daily gains estimated tended to be higher in the second period than in the first period. The heritability of body measurements at 12 months during the first period estimated was 0.30 for withers height, 0.25 for rump height, 0.11 for thurls width and 0.13 for chest girth. The heritability of body measurments at 12 months during the second period was 0.53 for withers height, 0.44 for rump height, 0.36 for thurls width and 0.56 for chest girth. The heritabilites of withers height, rump height, thurls width and chest girth at 18 months of age were $0.40,0.22,0.12$ and 0.21 during the first period and $0.45,0.42,0.42$ and 0.35 during the second period, respectively. The heritability of carcass traits estimated during the first period was 0.11 for carcass weight, 0.24 for dressing percent, 0.25 for eye muscle area, 0.18 for backfat thickness and 0.21 for carcass length. The heritabilities of carcass weight, dressing percent, eye muscle area, backfat thickness, carcass length and marbling score during the second period estimated were $0.32,0.52,0.33,0.51,0.58$ and 0.31 , respectively.

The genetic correlations between the first and second periods estimated were higher than 0.8 for chest girth at 12 months, rump height at 18 months, carcass weight and dressing percent, but were lower for other traits.

(Key words: Hanwoo bulls, Growth traits, Carcass traits, Genetic parameters, Multiple traits animal model)
\end{abstract}

Corresponding author : C. J. Park, Livestock Improvement Main Center, N.A.C.F., Wonbul-ri, Seosan-Si, 356-831 Korea. Tel : 041-663-4665. E-mail : pcjin1475@naver.com 


\section{I. 서 론}

1963년 한우를 육용우로 개량한다는 방향이 정해지고, 전국축산진흥대회 수상축 및 축산기 술연구소와 각 도종축장 당대검정우를 종모우 로 선발하여 정액을 생산 - 공급하였다. 1982년 농협중앙회 가축개량사업소가 설립된 후 가축 개량 개발계획에 의거 당대검정은 축산기술연 구소 대관령지소, 남원지소 및 각 도종축장에 서 실시하고 후대검정은 농협중앙회 가축개량 사업소에서 실시케 하여 당대 및 후대검정체계 를 구축하였고, 1987년 1차 후대검정을 완료하 여 보증종모우 10 두를 선발하였다.

한우 보증종모우 선발을 위한 유전능력평가 는 대조구를 이용한 최소자승법을 1994년까지 이용하였고, 그 이후부터 현재까지 Animal Model을 이용한 육종가 추정으로 보증종모우 를 선발하고 있으며, 후대검정 초기에는 증체 중심의 일당증체량, 18 개월체중, TDN 효율 및 도체성적(도체점수, 등지방두께, 도체율 및 정 육율) 등을 선발형질로 이용하였으나, 90년대 고급육 생산에 대한 관심이 고조되면서 92년부 터 6개월체중, 일당증체량 및 근내지방도를 선 발형질로 설정하였고, 후대검정우를 거세한 ' 99 년(23차)부터 선발형질을 도체중, 배최장근단면 적 및 근내지방도로 조정하여 현재에 이르고 있다.

또한 사양환경도 변화하여 1985년부터 1990 년까지(후대검정 상반기) 6 개월에 검정개시하 여 18 개월에 종료하였고, 단방식 및 계류식 우 사에서 개체관리하였다. 그러나, 18 개월 종료에 따른 근내지방도 출현율이 낮아 1991년부터 1996 년까지(후대검정 하반기) 검정기간을 10 개 월부터 22개월로 조정하여 군사식 우사에서 사 양관리하였으며 이 시기부터 혈액형검사에 의 한 친자확인을 실시하였다.

한우 후대검정자료를 이용한 유전모수 추정 은 신 등(1991)과 이 등(1991)이 연구 발표하였 으나 이는 후대검정 상반기 자료를 이용한 것
이었다. 따라서 본 연구는 비거세 후대검정을 실시한 1986년부터 1996년까지의 자료를 이용 하여 검정방법의 변화에 따른 12 개월령 및 18 개월령 경제형질과 도체 형질에 대한 유전 모 수를 추정하고, 환경 변화로 인한 후대검정 상 반기(2차 10 차)와 하반기(11차 22 차) 자료에 대한 분석모델을 제공하기 위하여 실시하였다.

\section{․ 재료 및 방법}

\section{1. 공시 재료}

본 연구는 1986년도부터 1996년도까지 농협 중앙회 가축개량사업소와 한우개량단지에서 생 산된 후 농협 가축개량사업소로 이동하여 후대 검정한 3,415두의 수소에 대한 검정 자료를 이 용하여 실시하였다.

후대검정 상반기는 생후 6개월에 개시하여 18 개월에 종료하였으나 혈액검사에 의한 친자 확인과 근내지방도에 대한 판정이 정립되지 않 았던 시기였고, 12 22차 후대검정(하반기)은 생후 10 개월에 개시하여 22 개월에 종료하였고, 친자확인과 근내지방도를 조사하였으므로 검정 방법에 차이가 있어 자료를 나눈 후 같은 형질 에 대하여 상반기집단과 하반기집단의 성적을 한 쌍으로 분석하였다. 출생 연도-계절별 및 출생지역별 두수는 Table 1과 같다.

\section{2. 조사 항목}

본 연구에서 조사된 형질은 체중, 일당증체 량, 체형 측정치 및 도체 형질이었으며 측정 방법은 다음과 같다.

12 개월, 18 개월 및 22 개월 체중은 매월 측정 한 체중을 각각 365 일, 540 일 및 670일로 보정 하였으며, 일당증체량은 개체별로 검정 개시일 령에 차이가 있어서 6 개월 체중, 12 개월 체중 및 18 개월 체중을 기준으로 계산하였다. 체형 측정은 12 개월령과 18 개월령에 체고, 십자부고, 
Table 1. Number of records by year-season of birth and location

\begin{tabular}{|c|c|c|c|c|c|c|c|c|c|}
\hline \multicolumn{5}{|c|}{ First period } & \multicolumn{5}{|c|}{ Second period } \\
\hline \multicolumn{2}{|c|}{ Year-season } & \multirow{2}{*}{$\frac{\text { No. }}{151}$} & \multirow{2}{*}{$\begin{array}{l}\text { Location } \\
\text { LIMC }\end{array}$} & \multirow{2}{*}{$\frac{\text { No. }}{1,096}$} & \multicolumn{2}{|c|}{ Year-season } & \multirow{2}{*}{$\begin{array}{l}\text { No. } \\
179\end{array}$} & \multirow{2}{*}{$\begin{array}{l}\text { Location } \\
\text { LIMC }\end{array}$} & \multirow{2}{*}{$\begin{array}{r}\text { No. } \\
1,241\end{array}$} \\
\hline Spring, & 86 & & & & Spring, & 91 & & & \\
\hline Fall, & 86 & 136 & HIA & 496 & Fall, & 91 & 139 & HIA & 582 \\
\hline Spring, & 87 & 165 & & & Spring, & 92 & 129 & & \\
\hline Fall, & 87 & 172 & & & Fall, & 92 & 174 & & \\
\hline Spring, & 88 & 178 & & & Spring, & 93 & 192 & & \\
\hline Fall, & 88 & 143 & & & Fall, & 93 & 195 & & \\
\hline Spring, & 89 & 186 & & & Spring, & 94 & 200 & & \\
\hline Fall, & 89 & 139 & & & Fall, & 94 & 148 & & \\
\hline Spring, & 90 & 173 & & & Spring, & 95 & 157 & & \\
\hline \multirow[t]{3}{*}{ Fall, } & 90 & 149 & & & Fall, & 95 & 149 & & \\
\hline & & & & & Spring, & 96 & 161 & & \\
\hline & & 1,592 & & 1,592 & & & 1,823 & & 1,823 \\
\hline
\end{tabular}

LIMC : Livestock Improvement Main Center HIA : Hanwoo Improvement Area.

곤폭 및 흉위에 대하여 측정하였다.

후대검정 종료 후 도축장으로 운송하여 도축 전 체중을 측정하였고, 24 시간 절식후 도축하 여 $0 \sim 5{ }^{\circ} \mathrm{C}$ 에서 24 시간이상 냉장시킨 후 좌우 반도체(左右 牛屠體) 중량을 측정하여 냉도체 중과 도체율을 계산하였으며, 배최장근단면적 은 최후 흉추와 제 1 요추 사이를 척추골과 직 각이 되게 절개한 후 최후 흉추쪽의 면적을 면 적자로 측정하였고, 등지방두께는 배최장근단 면적 측정부위에서 척추쪽으로 $2 / 3$ 안쪽으로 들 어간 지점에서 측정하였으며, 근내지방도는 배 최장근단면적 측정부위에서 지방침착도를 기준 표 $(1=$ 지방침착이 거의 없음, $\cdot \cdot \cdot, 5=$ 지 방침착이 매우 많음)와 비교하여 육안으로 측 정하였고, 도체장은 좌반도체 제 1 흥추에서 치 골부 하단 사이의 직선 거리를 측정하였다.

\section{3. 사양 관리}

후대검정에 공시된 검정대상우는 상반기의 경우 5 6개월에 입식하여 6개월령에서 18 개월 령까지 12 개월간 단방식 및 계류식 우사에서
개체별 사양관리를 실시하고, 농후사료와 조사 료를 자유채식 시켰다. 하반기는 5 6개월령에 입식하여 다두군사식 우사에서 집단 사양관리 를 실시한 후 10 개월령부터 22 개월령까지 10 두 군사식 우사에서 사양관리를 하였고, 농후사료 와 조사료는 자유채식 시켰다.

농후사료는 검정요령에 따라 농협중앙회 청 주사료공장에서 생산한 검정전기와 검정후기 사료를 급여하였고, 조사료는 검정기관의 사양 관리 체계에 따라 볏짚, 목건초, 목초펠렛 등을 급여하였다. 농후사료의 TDN 수준은 1986 1993 년까지 검정전기 6 개월간 $71.43 \%$, 후기 6 개월간 $72.29 \%$ 이었고, 그 후 검정전기는 $72 \%$, 후기는 $73 \%$ 이었다.

\section{4. 통계 분석}

각 형질에 대한 상가적 유전효과에 대한 유 전모수를 추정하기 위하여 다음의 다형질 혼합 모형을 이용하였다.

$$
\mathrm{Y}=\mathrm{Xb}+\mathrm{Zu}+\mathrm{e}
$$


여기서, $\mathrm{Y}$ 는 상반기와 하반기 형질에 대한 관측치 벡터이고, $\mathrm{X}$ 는 모델벡터로 출생년도계절 및 출생지역에 대한 고정효과와 발육형질 에 대한 개시일령(또는 도체형질에 대한 출하 일령)에 대한 선형 공변이이며, $\mathrm{b}$ 는 고정효과 에 대한 추정치 벡터이다. $Z$ 는 개체에 대한 임 의효과 벡터이고, $\mathrm{u}$ 는 개체에 대한 추정치 벡

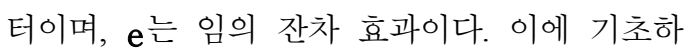
여 혼합모형 정규방정식은 다음과 같다.

$$
\left[\begin{array}{cc}
X^{-1} X & X^{-1} Z \\
Z R^{-1} X & Z R^{-1} Z+G^{-1}
\end{array}\right]\left[\begin{array}{c}
\widehat{b} \\
\widehat{u}
\end{array}\right]=\left[\begin{array}{c}
X^{-1} y \\
Z^{-1} y
\end{array}\right]
$$

본 연구에서는 분산치를 추정하기 위하여 MTDFREML Package(Van Vleck 등, 1993)를 사용하여 $\mathrm{G}\left(=\mathrm{V}(u)=\mathrm{A} \sigma_{\mathrm{g}}^{2}\right.$ :육종가벡터)와 $\mathrm{R}$ $\left(=\mathrm{V}(e)=\mathrm{I} \sigma_{\mathrm{e}}^{2}\right.$ :잔차벡터 $)$ 의 값에 임의의 초 기치를 주고, DF-REML(Derivative Free Restricted Maximum Likelihood) 방법으로 $\log$ likelihood 값의 차이가 $10^{-9}$ 이하에 도달할 때 를 수렴조건으로 하여 반복 추정하였으며, 최 종적으로 구해진 추정치를 초기치로 하여 재추 정하였다. 이렇게 추정한 분산성분과 공분산성 분을 이용하여 상반기와 하반기 후대검정자료
간의 유전상관 $\left(r_{G}\right)$ 을 추정하였다.

\section{III. 결과 및 고찰}

\section{1. 일반 능력}

본 연구에서 조사된 12 개월 체중, 18 개월 체 중 및 22개월 체중에 대한 일반평균과 표준편 차는 Table 2에 표시되어 있다. 12개월 체중의 경우 후대검정 상반기는 $324.3 \pm 38.1 \mathrm{~kg}$ 으로 하 반기의 $288.0 \pm 41.8 \mathrm{~kg}$ 보다 높게 나타났고, 18 개월 체중은 후대검정 상반기와 하반기가 각각 $465.3 \pm 47.4 \mathrm{~kg}$ 과 $\quad 460.8 \pm 54.6 \mathrm{~kg}$ 으로 차이가 적 었다. 이는 후대검정 상반기의 경우 6 개월령에 검정을 개시하여 단방식 및 계류식 우사에서 개체관리를 하였고, 하반기는 6 개월 10 개월령 까지 다두군사식 우사에서 사양관리를 실시하 다가 검정이 개시되는 10 개월령부터 10 두 군사 식 우사에서 사양관리를 실시한데서 오는 환경 효과로 사료되며, 12 개월 체중은 나 등(1992)의 결과와 비슷한 경향을 나타내었으나 신 등 (1990)의 결과보다 낮게 추정되었으며, 18 개월 체중은 신 등(1990)의 결과와 비슷하였다.

Table 2에서 제시한 바와 같이 6 개월 12 개 월 일당증체량은 상반기의 경우 $1.01 \pm 0.15 \mathrm{~kg}$ 으 로 하반기의 $0.80 \pm 0.18 \mathrm{~kg}$ 보다 높았으나, 12 개

Table 2. Means and standard deviations of starting age, body weights at 12,18 and 22 months and average daily gains

\begin{tabular}{lcc}
\hline Trait & 1st period & 2nd period \\
\hline \hline Starting age(day) & $225.4 \pm 9.2$ & $330.7 \pm 8.4$ \\
12 months BW(kg) & $324.3 \pm 38.1$ & $288.0 \pm 41.8$ \\
18 months BW(kg) & $465.3 \pm 47.4$ & $460.8 \pm 54.6$ \\
22 months BW(kg) & - & $551.7 \pm 62.4$ \\
\hline ADG1 $(\mathrm{kg})$ & $1.01 \pm 0.15$ & $0.80 \pm 0.18$ \\
ADG2(kg) & $0.77 \pm 0.17$ & $0.95 \pm 0.19$ \\
\hline
\end{tabular}

ADG1 $=$ average daily gain during $6 \sim 12$ months.

$\mathrm{ADG} 2=$ average daily gain during $12 \sim 18$ months. 
월 18 개월 일당증체량은 후대검정 하반기가 $0.95 \pm 0.19 \mathrm{~kg}$ 으로 후대검정 상반기의 $0.77 \pm$ $0.17 \mathrm{~kg}$ 보다 높게 추정되어 하반기에 보상성장 의 효과가 나타난 것으로 사료된다. 전반기의 일당증체량은 신 등(1990)의 결과와 비슷하였 고, 전반기 6 12개월 일당증체량은 Veseth 등 (1993)의 Hereford 수소에 대한 이유후 일당증 체량 $1.16 \mathrm{~kg}$ 보다 낮았으나 Hirooka 등(1996)의 갈모화우에 대한 일당증체량 $0.979 \mathrm{~kg}$ 및 Beever 등(1990)의 Angus 수소 이유후 일당증체량 0.94 $\mathrm{kg}$ 보다 높았다.

12 개월과 18 개월 체형 측정치는 Table 3 에 나타나 있다. 후대검정 상반기의 12 개월 체고, 십자부고, 곤폭 및 흉위는 각각 $118.7 \pm 4.47 \mathrm{~cm}$, $122.5 \pm 4.33 \mathrm{~cm}, \quad 38.6 \pm 2.76 \mathrm{~cm}$, 및 $174.2 \pm 7.27 \mathrm{~cm}$ 이었으며, 하반기는 $\quad 114.9 \pm 6.62 \mathrm{~cm}, \quad 117.6 \pm$
$6.67 \mathrm{~cm}, \quad 36.2 \pm 4.05 \mathrm{~cm}$ 및 $155.2 \pm 12.83 \mathrm{~cm}$ 로 상 반기가 하반기보다 높게 측정되었다. 후대검정 상반기 18 개월 체고, 십자부고, 곤폭 및 흉위는 각각 $\quad 125.0 \pm 4.72 \mathrm{~cm}, \quad 128.1 \pm 4.68 \mathrm{~cm}, \quad 42.2 \pm$ $3.22 \mathrm{~cm}$ 및 $189.7 \pm 7.97 \mathrm{~cm}$ 이였고, 하반기는 각 각 $127.1 \pm 4.25 \mathrm{~cm}, \quad 129.3 \pm 4.23 \mathrm{~cm}, \quad 43.8 \pm 3.39 \mathrm{~cm}$ 및 $189.1 \pm 9.98 \mathrm{~cm}$ 로 추정되어, 체고, 십자부고 및 곤폭은 하반기가 높게 추정되었고, 흉위는 상반기에 높게 추정되었으나 그 차이는 크지 않았다.

도체 형질에 대한 일반능력은 Table 4에 표 시되어 있다. 후대검정 상반기는 18 개월에 검 정을 종료하여 도축일령이 $588.3 \pm 20.16$ 일이었 고, 냉도체중, 도체율, 배최장근단면적, 등지방 두께 및 도체장은 각각 $273.3 \pm 30.86 \mathrm{~kg}, 58.8 \pm$ $1.72 \%, \quad 79.2 \pm 9.10 \mathrm{~cm}^{2}, \quad 0.73 \pm 0.38 \mathrm{~cm}$ 및 $129.7 \pm$

Table 3. Means and standard deviations of body measurements at 12 and 18 months of age $(\mathrm{cm})$

\begin{tabular}{|c|c|c|c|c|}
\hline \multirow{2}{*}{ Trait } & \multicolumn{2}{|c|}{12 months of age } & \multicolumn{2}{|c|}{18 months of age } \\
\hline & 1st period & 2nd period & 1st period & 2nd period \\
\hline Withers height & $\begin{array}{l}118.70 \\
\pm 4.47\end{array}$ & $\begin{array}{l}114.89 \\
\pm 6.62\end{array}$ & $\begin{array}{l}125.03 \\
\pm 4.72\end{array}$ & $\begin{array}{l}127.12 \\
\pm 4.25\end{array}$ \\
\hline Rump height & $\begin{array}{l}122.46 \\
\pm 4.33\end{array}$ & $\begin{array}{l}117.63 \\
\pm 6.67\end{array}$ & $\begin{array}{l}128.07 \\
\pm 4.68\end{array}$ & $\begin{array}{l}129.28 \\
\pm 4.23\end{array}$ \\
\hline Thurls width & $\begin{aligned} & 38.61 \\
\pm & 2.76\end{aligned}$ & $\begin{aligned} & 36.22 \\
\pm & 4.05\end{aligned}$ & $\begin{aligned} & 42.15 \\
\pm & 3.22\end{aligned}$ & $\begin{aligned} & 43.84 \\
\pm & 3.39\end{aligned}$ \\
\hline Chest girth & $\begin{array}{l}174.18 \\
\pm 7.27\end{array}$ & $\begin{aligned} & 155.18 \\
\pm & 12.83\end{aligned}$ & $\begin{array}{l}189.67 \\
\pm 7.97\end{array}$ & $\begin{array}{l}189.12 \\
\pm 9.98\end{array}$ \\
\hline
\end{tabular}

Table 4. Means and standard deviations of carcass traits

\begin{tabular}{lcc}
\hline Trait & 1st period & 2nd period \\
\hline \hline Slaughter age(day) & $588.30 \pm 20.16$ & $698.84 \pm 26.82$ \\
Carcass weight $(\mathrm{kg})$ & $273.27 \pm 30.86$ & $320.93 \pm 38.70$ \\
Dresing percentage $(\%)$ & $58.76 \pm 1.72$ & $58.72 \pm 1.81$ \\
Eye muscle area $\left(\mathrm{cm}^{2}\right)$ & $79.23 \pm 9.10$ & $80.30 \pm 9.67$ \\
Back fat thickness $(\mathrm{cm})$ & $0.73 \pm 0.38$ & $0.47 \pm 0.26$ \\
Carcass length $(\mathrm{cm})$ & $129.69 \pm 5.71$ & $133.80 \pm 4.56$ \\
Marbling score & - & $1.58 \pm 0.90$ \\
\hline
\end{tabular}


$5.17 \mathrm{~cm}$ 이었다. 하반기는 22 개월에 검정을 종료 하여 도축일령이 상반기와 약 100 일 차이가 난 $698.8 \pm 26.82$ 일이었고, 냉도체중, 도체율, 배최 장근단면적, 등지방두께, 도체장 및 근내지방도 는 각각 $\quad 320.9 \pm 38.70 \mathrm{~kg}, \quad 58.7 \pm 1.81 \%, \quad 80.3 \pm$ $9.67 \mathrm{~cm}^{2}, \quad 0.47 \pm 0.26 \mathrm{~cm}, \quad 133.8 \pm 4.56 \mathrm{~cm}$ 및 1.58 \pm 0.90 으로 추정되었다.

상반기 후대검정 집단의 도체성적를 Wilson 등(1993)의 Angus 거세우 527일령 도체성적과 Herring 등(1994)의 Hereford 교잡종 거세우 500 일령 도체성적과 비교하면 배최장근단면적은 넓었고, 등지방두께는 얇았으나 도체중은 낮았 다. 그리고 신 등(1990)의 등지방두께 추정치보 다 얇았다. 하반기 후대검정 집단의 경우 Lunt 등(1992)이 Angus 거세우를 25.9개월령에 도축 하여 조사한 도체중 $467.1 \mathrm{~kg}$ 및 배최장근단면 적 $82.3 \mathrm{~cm}^{2}$ 보다 낮았으나 등지방두께 $3.3 \mathrm{~cm}$ 보 다 얇았고, 일본 등급판정기준에 의한 근내지 방도 4.5보다 낮았으며, Hirooka 등(1996)이 일 본 갈모화우의 현장자료를 분석한 결과 도축일 령 724 일령에, 도체중은 $437.0 \mathrm{~kg}$, 등지방두께 $2.6 \mathrm{~cm}$ 및 근내지방도 3.7 으로 하반기 집단보다 도체중과 근내지방도는 높았으나 등지방두께는 두꺼웠다.

\section{2. 유전력 및 상 - 하반기 집단간 유전상관}

후대검정 상반기와 하반기의 자료를 다형질 Animal Model을 이용하여 추정한 체중과 일당 증체량에 대한 유전력을 Table 5에 표시하였다. 후대검정 상반기의 자료로 추정한 12 개월 체중 과 18 개월 체중의 유전력은 0.37 와 0.29 이었고, 하반기의 자료로 추정한 12 개월 체중, 18 개월 체중 및 22 개월 체중에 대한 유전력이 각각 $0.47,0.33$ 및 0.31 으로 상반기보다 하반기에서 높게 추정되었으며, 상-하반기 집단간 12 개월 및 18 개월 체중의 유전상관은 각각 0.77 과 0.48 로 추정되었다.

12 개월 체중의 유전력은 이와 오(1985)의 결 과와 비슷하였으나, Shin과 $\operatorname{Park}(1990)$ 의 결과 보다 낮게 추정되었고, 18 개월 체중의 유전력 은 Shin과 Park(1990) 및 Kemp 등(1984)의 추 정치와 비슷하였으나, 신 등(1991)의 결과보다 낮았고, 이와 오(1985)과 최 등(1996)의 보고보 다 높게 추정되었다. 22개월 체중은 이와 오 (1985)의 연구 결과보다 낮게 추정되었다.

후대검정 상반기의 $6 \sim 12$ 개월과 $12 \sim 18$ 개월 일당증체량의 유전력은 0.26 과 0.11 로 신 등 (1991)의 결과보다 낮게 추정되었고, 후대검정 하반기의 경우 각각 0.33 과 0.22 으로 상반기보

Table 5. Genetic variances $\left(\sigma_{\mathrm{a}}^{2}\right)$, residual variances $\left(\sigma_{\mathrm{e}}^{2}\right)$ and heritabilities $\left(h^{2}\right)$ of body weights and average daily gains and genetic correlations $\left(r_{G}\right)$ between 1 st and 2 nd periods for each trait

\begin{tabular}{|c|c|c|c|c|c|c|c|}
\hline \multirow{2}{*}{ Trait } & \multicolumn{3}{|c|}{ 1st period } & \multicolumn{3}{|c|}{ 2nd period } & \multirow{2}{*}{$r_{G}$} \\
\hline & $\sigma_{a}^{2}$ & $\sigma_{e}^{2}$ & $h^{2}$ & $\sigma_{a}^{2}$ & $\sigma_{e}^{2}$ & $h^{2}$ & \\
\hline 12 months BW & 412.6 & 699.6 & 0.37 & 428.6 & 490.2 & 0.47 & 0.77 \\
\hline 18 months BW & 573.4 & $1,374.2$ & 0.29 & 650.1 & $1,299.1$ & 0.33 & 0.48 \\
\hline 22 months BW & - & - & - & 892.0 & $2,002.1$ & 0.31 & - \\
\hline ADG1 & 49.9 & 142.1 & 0.26 & 57.9 & 118.2 & 0.33 & 0.69 \\
\hline ADG2 & 30.0 & 234.9 & 0.11 & 59.2 & 204.6 & 0.22 & 0.56 \\
\hline
\end{tabular}

ADG1 $=$ average daily gain during $6 \sim 12$ months.

ADG2 = average daily gain during $12 \sim 18$ months. 
다 높게 추정되었으나 Veseth 등(1993)이 추정 한 Hereford 수소에 대한 105일령부터 465일령 까지의 일당증체량에 대한 유전력 0.47 보다 낮 았다. 그리고 $6 \sim 12$ 개월 및 12 18개월 일당증 체량의 상-하반기 집단간 유전상관은 0.69 와 0.56 으로 추정되었다.

Table 6은 12개월 체형 측정치의 유전력과 상-하반기 집단간 유전상관 추정결과를 제시 한 것이다. 후대검정 상반기 집단의 체고, 신자 부고, 곤폭 및 흉위에 대한 유전력은 각각 $0.30,0.25,0.11$ 및 0.13 이었으며, 하반기의 경 우 각각 $0.53,0.44,0.36$ 및 0.56 으로 하반기 집단의 유전력이 상반기 집단보다 높았고, 상 하반기 집단간 유전상관은 체고, 십자부고, 곤 폭 및 흉위에서 각각 $0.20,0.21,0.54$ 및 0.86 으로 흉위에서 높은 정의 상관을 나타내었다.

18 개월 체형 측정치에 대한 유전력과 상 - 하
반기 집단간 유전상관은 Table 7에 제시되었다. 상반기 집단의 경우 체고, 십자부고, 곤폭 및 흉위에 대한 유전력은 각각 $0.40,0.22,0.12$ 및 0.21 로 추정되었고, 하반기의 경우 $0.45,0.42$, 0.42 및 0.35 로 추정되어 하반기 집단의 유전력 이 높게 나타나 체중 및 일당증체량 비슷한 경 향을 나타냈다. 그리고 상 - 하반기 집단간 유 전상관은 체고, 십자부고, 곤폭 및 흉위에 대하 여 각각 $0.68,0.80,0.65$ 및 0.47 로 십자부고에 서 높게 추정되었다.

12 개월 체형에 대한 유전력은 $\mathrm{Kim}$ 등(1997) 보다 높게 추정되었고, 18 개월 체형에 대한 유 전력은 이와 오(1985)의 결과보다 낮게 추정되 었다.

Table 8은 후대검정우에 대한 도체 형질의 유전력을 제시한 것으로 상반기 집단의 경우 냉도체중, 도체율, 배최장근단면적, 등지방두께

Table 6. Genetic variances $\left(\sigma_{\mathrm{a}}^{2}\right)$, residual variances $\left(\sigma_{\mathrm{e}}^{2}\right)$ and heritabilities $\left(h^{2}\right)$ of body measurements at 12 months and genetic correlations $\left(r_{G}\right)$ between 1 st and 2 nd periods for each trait

\begin{tabular}{|c|c|c|c|c|c|c|c|}
\hline \multirow{2}{*}{ Trait } & \multicolumn{3}{|c|}{ 1st period } & \multicolumn{3}{|c|}{ 2nd period } & \multirow{2}{*}{$r_{G}$} \\
\hline & $\sigma_{a}^{2}$ & $\sigma_{e}^{2}$ & $h^{2}$ & $\sigma_{a}^{2}$ & $\sigma_{e}^{2}$ & $h^{2}$ & \\
\hline Withers height & 4.10 & 9.53 & 0.30 & 7.45 & 6.57 & 0.53 & 0.20 \\
\hline Rump height & 3.29 & 10.14 & 0.25 & 6.39 & 8.05 & 0.44 & 0.21 \\
\hline Thurls width & 0.56 & 4.36 & 0.11 & 2.22 & 4.00 & 0.36 & 0.54 \\
\hline Chest girth & 5.02 & 33.85 & 0.13 & 24.37 & 18.79 & 0.56 & 0.86 \\
\hline
\end{tabular}

Table 7. Genetic variances $\left(\sigma_{a}^{2}\right)$, residual variances $\left(\sigma_{e}^{2}\right)$ and heritabilities $\left(h^{2}\right)$ of body measurements at 18 months and genetic correlations $\left(r_{G}\right)$ between 1st and 2 nd periods for each trait

\begin{tabular}{|c|c|c|c|c|c|c|c|}
\hline \multirow{2}{*}{ Trait } & \multicolumn{3}{|c|}{ 1st period } & \multicolumn{3}{|c|}{ 2nd period } & \multirow{2}{*}{$r_{G}$} \\
\hline & $\sigma_{a}^{2}$ & $\sigma_{e}^{2}$ & $h^{2}$ & $\sigma_{a}^{2}$ & $\sigma_{e}^{2}$ & $h^{2}$ & \\
\hline Withers height & 5.91 & 8.99 & 0.40 & 5.69 & 7.09 & 0.45 & 0.68 \\
\hline Rump height & 3.56 & 12.68 & 0.22 & 5.66 & 7.69 & 0.42 & 0.80 \\
\hline Thurls width & 0.75 & 5.64 & 0.12 & 3.17 & 4.37 & 0.42 & 0.65 \\
\hline Chest girth & 9.34 & 35.37 & 0.21 & 15.62 & 29.37 & 0.35 & 0.47 \\
\hline
\end{tabular}


Table 8. Genetic variances $\left(\sigma_{a}^{2}\right)$, residual variances $\left(\sigma_{e}^{2}\right)$ and heritabilities $\left(h^{2}\right)$ of carcass traits and genetic correlations $\left(r_{G}\right)$ between 1 st and 2 nd periods for each trait

\begin{tabular}{|c|c|c|c|c|c|c|c|}
\hline \multirow{2}{*}{ Trait } & \multicolumn{3}{|c|}{ 1st period } & \multicolumn{3}{|c|}{ 2nd period } & \multirow{2}{*}{$r_{G}$} \\
\hline & $\sigma_{a}^{2}$ & $\sigma_{e}^{2}$ & $h^{2}$ & $\sigma_{a}^{2}$ & $\sigma_{e}^{2}$ & $h^{2}$ & \\
\hline Carcass weight & 85.94 & 688.12 & 0.11 & 362.62 & 757.62 & 0.32 & 0.98 \\
\hline Dressing percentage & 0.68 & 2.15 & 0.24 & 1.55 & 1.41 & 0.52 & 0.97 \\
\hline Eye muscle area & 18.37 & 55.55 & 0.25 & 23.73 & 32.30 & 0.33 & 0.31 \\
\hline Backfat thickness & 0.02 & 0.09 & 0.18 & 0.03 & 0.03 & 0.51 & 0.44 \\
\hline Carcass length & 4.74 & 17.85 & 0.21 & 9.80 & 7.13 & 0.58 & 0.66 \\
\hline Marbling score & - & - & - & 0.17 & 0.38 & 0.31 & - \\
\hline
\end{tabular}

및 도체장에 대한 유전력이 각각 $0.11,0.24$, $0.25,0.18$ 및 0.21 로 비교적 낮게 추정되었고, 하반기의 경우 각각 $0.32,0.52,0.33,0.51$ 및 0.58 으로 추정되어 상반기 추정치보다 높았으 며 근내지방도의 유전력은 0.31 로 추정되었다. 도체중과 도체율에 대한 상 - 하반기 집단간 유 전상관은 각각 0.98 과 0.97 로 추정되었고, 배최 장근단면적, 등지방두께 및 도체장의 상 - 하반 기 집단간 유전상관은 각각 $0.31,0.44$ 및 0.66 으로 추정되었다.

하반기 집단에 대한 도체중의 유전력은 Veseth 등(1993), Marshall (1994) 및 Hirooka 등 (1996)의 결과보다 낮았으나 Wilson 등(1993)의 도체중에 대한 유전력 0.31 보다 높았고, 배최장 근단면적의 유전력은 Veseth 등(1993), Marshall (1994) 및 Hirooka 등(1996)의 추정치보다 낮았 으며, 등지방두께의 유전력은 Wilson 등(1993), Marshall (1994) 및 Hirooka 등(1996)의 결과보 다 높았다. 그리고 근내지방도의 유전력은 Marshall (1994) 및 Hirooka 등(1996)의 유전력 추정치 0.44와 0.40 보다 낮았으나 Veseth 등 (1993)의 결과와 같았으며 Wilson 등(1993)의 결과보다 높았다.

상 - 하반기 집단간 유전상관은 12 개월 체중 과 흉위, 18 개월 십자부고 및 도체중과 도체율 에 대하여만 높게 나타났을 뿐 다른 형질들은
낮게 나타났다. 이러한 결과는 Lee와 Bertrand (2002)가 Meyer의 연구를 인용하여 다른 환경 에서 조사된 같은 형질에 대한 유전상관이 0.8 정도일 때 생물학적 측면에서 유전과 환경 상 호작용이 존재하지 않는 것으로 간주한 것에 근거하면 상반기와 하반기 후대검정 집단간 검 정환경 차에 의하여 환경과 유전간의 상호작용 이 존재하는 것으로 사료된다.

$$
\text { IV. 요 약 }
$$

본 연구는 농협중앙회 가축개량사업소와 한 우개량단지에서 생산된 비거세 한우 숫소 3,415 두의 자료를 이용하여 성장형질과 도체형 질에 대한 유전모수를 추정하기 위하여 실시하 였다. 본 연구에 이용된 한우 집단은 상반기와 하반기의 두 집단으로 구분하였는데 상반기 집 단은 1986년부터 1990년까지 생산된 숫소 1,592 두로서 6 개월에 검정개시하여 18 개월에 종료하였고, 단방식 우사에서 개체관리를 하였 다. 하반기 집단은 1991년부터 1996년까지 출 생한 1,823 두로 10 개월에 검정개시하여 22 개월 에 종료하였고, 군사식 우사에서 사양관리 하 였다. 6 12개월과 $12 \sim 18$ 개월 일당증체량은 상반기 집단의 경우 $1.01 \mathrm{~kg}$ 과 $0.77 \mathrm{~kg}$ 이였고, 하 반기 집단은 $0.80 \mathrm{~kg}$ 과 $0.95 \mathrm{~kg}$ 으로 하반기 집단 
에서 보상성장이 일어난 것으로 사료된다.

12 개월 및 18 개월 체중의 유전력은 상반기 집단의 경우 0.37 및 0.29 이었고, 하반기 집단 은 0.47 및 0.33 이었으며, $6 \sim 12$ 개월 및 $12 \sim 18$ 개월 일당증체량의 유전력은 상반기 집단에서 0.26 및 0.11 이었고, 하반기 집단은 0.33 및 0.22 으로 이들 형질의 유전력은 하반기에서 높 았다. 상반기 집단의 12 개월령 체고, 십자부고, 곤폭 및 흉위에 대한 유전력은 각각 $0.30,0.25$, 0.11 및 0.13 이었으며, 하반기의 경우 각각 $0.53,0.44,0.36$ 및 0.56 이었다. 상반기 집단의 18 개월령 체고, 십자부고, 곤폭 및 흉위의 유전 력은 각각 $0.40,0.22,0.12$ 및 0.21 이었고, 하반 기의 경우 각각 $0.45,0.42,0.42$ 및 0.35 이었다. 상반기 집단의 냉도체중, 도체율, 배최장근단면 적, 등지방두께 및 도체장에 대한 유전력은 각 각 $0.11,0.24,0.25,0.18$ 및 0.21 이었고, 하반기 집단의 경우 각각 $0.32,0.52,0.33,0.51$ 및 0.58 이었으며, 근내지방도의 유전력은 0.31 이었 다.

상 - 하반기간 유전상관의 추정치는 12 개월 흉위, 18 개월 십자부고, 도체중 및 도체율의 경 우 0.8 이상이었으나 다른 형질에서의 추정치 는 이보다 낮았다.

\section{$\mathrm{V}$. 인 용 문 헌}

1. Beever, J. E., George, P. D., Fernando, R. L., Stormont, C. J. and Lewin, H. A. 1990. Associations between genetic markers and growth and carcass traits in a paternal half-sib family of Angus cattle. J. Anim. Sci. 68:337-344.

2. Herring W. O., Wiliams, S. E., Bertrand, J. K., Benyshek, L. L. and Miller, D. C. 1994. Comparison of live and carcass equations predicting percentage of cutability, retail product weight and trimmable fat in beef cattle. J. Anim. Sci. 72:1107-1118.

3. Hirooka H., Groen, A. F. and Matsumoto, M. 1996. Genetic parameters for growth and carcass traits in Japanese Brown Cattle estimated from field records. J. Anim. Sci. 74:2112-2116.

4. Kemp, R. A., Schaeffer, L. R. and Wilton, J. W. 1984. Comparison of beef sire evaluation models for an organized progeny test. J. Anim. Sci. 58: 1313-1320.

5. Kim H. C., Seo, K. S., Cho, Y. M., Lee, D. H., Park, Y. I., Cho, B. D. and Choi, J. K. 1997. Estimation on heritabilities and genetic progress for body weight and body measurements at 30 months of age in Hanwoo. Animal Genetics and Breeding. 1(4):273-276.

6. Lee, D. H. and Bertrand, J. K. 2002. Investigation of genotype country interactions for growth traits in beef cattle. J. Anim. Sci. 80:330-337.

7. Lunt, D. K., Riley, R. R. and Smith, S. B. 1992. Growth and carcass characterisitcs of Angus and American Wagyu steers. Meat Science. 34:327334.

8. Marshall, D. M. 1994. Breed differences and genetic paramaters for body composition traits in beef cattle. J. Anim. Sci. 72:2745-2755.

9. Shin O. Y. and Park, Y. I. 1990. Estimation of genetic parameters for body weights of Korean Native Cattle. Korean. J. Anim. Sci. 32(6):315317.

10. Van Vleck L. D., Boldman, K. G., Krises, L. A. and Kachman, S. D. 1993. A manual for use of MTDFREM. USDA. ARS.

11. Veseth, D. A., Reynolds, W. L., Uriks, J. J., Nelsen, T. C., Short, R. E. and Kress, D. D. 1993. Paternal half-sib heritabilities and genetic, environmental, and phenotypic correlation estimates from randomly selected Hereford Cattle. J. Anim. Sci. 71:1730-1736.

12. Wilson, D. E., Willham, R. L., Northcutt, S. L. and Rouse, G. H. 1993. Genetic parameters for carcass traits estimated from Angus field record. J. Anim. Sci. 71:2365-2370.

13. 나승환, 백동훈, 신원집, 정창화, 정연후, 강수원. 1992. 한우의 주요 경제형질에 대한 환경 요인의 효과. 한국동물자원과학회지. 34(1):1-9.

14. 신언익, 김종복, 한광진, 박영일. 1990. 한우의 경 제형질에 대한 환경 요인의 효과. 한국동물자원 과학회지. 32(4):184-189.

15. 신언익, 이문걸, 이득환. 1991. 한우의 종모우 평 
가방법에 관한 연구 I. 증체 및 도체 형질에 대 한 유전 모수 추정. 한국동물자원과학회지. 33 (12):817-822.

16. 이득환, 이문걸, 신언익. 1991. 한우의 종모우 평 가벙법에 관한 연구 $\Pi$. 선발지수법과 BLUP에 의한 단형질 및 다형질 평가방법의 비교. 한국동 물자원과학회지 33:823-830.
17. 이문연, 오봉국. 1985. 한우의 체중과 체형체측치 간의 상관관계 및 유전력 추정. 한국동물자원과 학회지. 27(11):691-695.

18. 최호성, 백동훈, 최광수. 1996. 한우의 체중 및 체위형질에 대한 유전력 및 유전 상관의 추정. 한국동물자원과학회지. 38(5):463-470.

(접수일자 : 2002. 11. 26 / 채택일자 : 2003. 2. 10) 